\title{
EFEK SUBSITUSI PUPUK UREA DENGAN PUPUK BIO SLURRY TERHADAP PRODUKTIVITAS RUMPUT BENGGALA (Panicum maximum cv. Trichoglume)
}

\author{
Witariadi N.M., dan N. N. C. Kusumawati \\ Fakultas Peternakan, Universitas Udayana \\ Email: witarimade @yahoo.com
}

\begin{abstract}
ABSTRAK
Percobaan untuk mengetahui efek subsitusi pupuk urea dengan pupuk bio slurry terhadap produktivitas rumput Panicum maximum cv. Trichoglume. Percobaan dilaksanakan di rumah kaca berlangsung selama 3 bulan. Rancangan yang digunakan adalah rancangan acak lengkap (RAL), dengan tujuh perlakuan dan setiap perlakuan diulang lima kali. Perlakuan tersebut adalah dosis $200 \mathrm{~kg}$ urea/ha (A); $150 \mathrm{~kg} \mathrm{urea} / \mathrm{ha}+10$ ton bio slurry sapi/ha (B); $100 \mathrm{~kg}$ urea /ha +20 ton bio slurry sapi/ha (C); $50 \mathrm{~kg}$ urea/ha +30 ton bio slurry sapi/ha (D); $150 \mathrm{~kg}$ urea/ha+ 10 ton bio slurry babi/ha (E); $100 \mathrm{~kg}$ urea/ha +20 ton bio slurry babi /ha (F); $50 \mathrm{~kg}$ urea/ha +30 ton bio slurry babi/ha (G). Variabel yang diamati meliputi: tinggi tanaman, jumlah anakan, jumlah cabang, jumlah daun, berat kering daun, berat kering batang, berat kering total hijauan, luas daun per pot, dan nisbah berat kering daun dengan berat kering batang. Hasil penelitian menunjukkan bahwa efektivitas substitusi pupuk urea dengan bio slurry babi memberikan hasil terbaik terhadap pertumbuhan dan produksi rumput Panicum maximum cv. Trichoglume, dimana perlakuan (G) yaitu substitusi $50 \mathrm{~kg}$ urea /ha +30 ton bio slurry babi/ha memberikan hasil tertinggi. Dapat disimpulkan untuk meningkatkan pertumbuhan dan produksi rumput Panicum maximum cv Trichoglume dapat disubstitusi dengan $50 \mathrm{~kg}$ urea/ha +30 ton bio slurry babi/ha.
\end{abstract}

Kata kunci: subsitusi, urea, bio slurry, produktivitas, Panicum maximum

\begin{abstract}
This experiment to determine the effect of substitution of urea fertilizer with bio slurry fertilizer on productivity of Panicum maximum cv. Trichoglume grass. The experiment was conducted in a greenhouse for 3 months. The design was used completely randomized design (CRD), with seven treatments and each treatment repeated five times. The treatment was dosage of 200 urea $\mathrm{kg} / \mathrm{ha}(\mathrm{A}) ; 150 \mathrm{~kg} \mathrm{urea} / \mathrm{ha}+10$ tons cow bio slurry /ha (B); $100 \mathrm{~kg}$ urea/ha +20 tons cow bio slurry/ha (C); $50 \mathrm{~kg}$ urea/ha +30 tons cow bio slurry/ha (D); $150 \mathrm{~kg}$ urea/ha + 10 tons pig bio slurry/ha (E); $100 \mathrm{~kg}$ urea/ha +20 tons pig bio slurry/ha (F); $50 \mathrm{~kg}$ urea/ha +30 tons pig bio slurry/ha (G). Variables observed were plant height, number of tillers, number of branches, number of leaves, leaf dry weight, stem dry weight, total forage dry weight, leaf area per pot, and leaf dry weight ratio with stem dry weight. The results showed that the effectiveness of urea fertilizer substitution with pig bio slurry gave the best growth and production of grass Panicum maximum cv. Trichoglume, where treatment $(\mathrm{G})$ with substitution of $50 \mathrm{~kg}$ urea/ha +30 tons pig bio slurry/ha gave the highest yield. It can be concluded increasng of growth and production of grass Panicum maximum cv. Trichoglume can be substituted with $50 \mathrm{~kg}$ urea/ha +30 tons pig bio slurry/ha.
\end{abstract}

Keywords: substitution, urea, bio slurry, productivity, Panicum maximum

\section{PENDAHULUAN}

Keberhasilan usaha peternakan, khususnya ruminansia sangat tergantung dari kecukupan tersedianya pakan hijauan, baik jumlah maupun mutunya. Sumber pakan bagi ternak ruminansia hampir $70 \%$ dari jumlah yang diberikan terdiri dari hijauan (Tata, 1995). Tingginya kebutuhan akan sumber hijauan, maka perlu adanya perhatian dalam penyediaan baik dari segi kuantitas maupun kualitas. Pakan dengan kualitas baik dan kuantitas yang cukup serta tersedia sepanjang tahun, untuk menjaga kelangsungan produksi dan meningkatkan produktivitas ternak ruminansia. Produktivitas ternak dapat ditingkatkan dengan memberikan pakan secara optimal, karena itu kualitas pakan harus diperhatikan agar ternak tumbuh secara maksimal. Perlu dikembangkan jenis hijauan unggul yang pertumbuhannya tidak dipengaruhi oleh musim. Salah satu alternatif untuk meningkatkan produksi hijauan pakan ternak adalah dengan mengembangkan jenis rumput Panicum maximum cv. Trichoglume. 
Rumput Panicum maximum cv. Trichoglume merupakan salah satu jenis tanaman makanan ternak yang memiliki kualitas baik untuk memenuhi kebutuhan ternak ruminansia. Rumput Panicum maximum cv.Trichoglume termasuk tanaman pakan berumur panjang, dapat beradaptasi dengan semua jenis tanah, tahan terhadap naungan dan palatabel (disukai ternak). Kualitas nutrisi dari rumput Panicum maximum cv. Trichoglume mengandung protein sebesar: 5,0\% sampai 5,6\% (Aganga dan Tshwenyane, 2004). Terbatasnya lahan yang digunakan untuk melakukan penanaman hijauan pakan akibat lahan diutamakan untuk penanaman tanaman pangan, keadaan tersebut menyebabkan usaha penyediaan hijauan pakan mengarah pada lahan yang memiliki kondisi lahan kering (Suarna, 1997).

Lahan kering umumnya memiliki unsur hara rendah, dimana kandungan unsur hara tersedia dalam jumlah sedikit di tanah. Usaha meningkatkan kandungan hara tanah dengan melakukan pemupukan. Pemupukan dimaksudkan untuk mencukupi kebutuhan hara tanah supaya potensi genetik tanaman dapat dikembangkan secara maksimal. Melalui pemupukan kesuburan lahan garapan dapat dipertahankan atau bahkan dapat ditingkatkan, sehingga dapat meningkatkan produktivitas dari tanaman rumput yang dibudidayakan (Rustandi, 1982). Pemupukan dengan pupuk $\mathrm{N}$ pada rumput memiliki kelebihan dimana sangat potensial dalam meningkatkan produksi bahan kering serta mempengaruhi susunan kimia tanah, seperti protein dan serat kasar (Deinum, 1966). Jenis pupuk urea dan bio slurry merupakan salah satu pupuk yang dapat digunakan untuk meningkatkan hasil produksi hijauan. Pupuk urea adalah pupuk kimia mengandung nitrogen $(\mathrm{N})$ berkadar tinggi (46\%).

Unsur nitrogen merupakan zat hara yang sangat diperlukan tanaman. Penggunaan pupuk urea sebagai sumber nitrogen secara berlebihan, akan mengancam kelangsungan hidup mikroorganisme yang berada dalam tanah, untuk itu perlu diimbangi dengan pemakaian pupuk organik (bio slurry). Bio slurry merupakan produk akhir pengolah limbah (biogas) berbahan kotoran sapi atau babi berbentuk padat. Dengan memberikan perlakuan melalui tehnologi fermentasi yang bertujuan mempercepat proses perombakan bahan organik sehingga unsur hara lebih cepat tersedia untuk pertumbuhan tanaman. Bio slurry sangat baik untuk memperbaiki struktur tanah, sebagai sumber nutrisi untuk tanaman (mengandung mikroba pro-biotik yang bermanfaat meningkatkan kesuburan lahan pertanian), meningkatkan kemampuan tanah mengikat atau menahan air lebih lama, meningkatkan aktivitas cacing dan mikroorganisme tanah. Komposisi nutrisi bio slurry adalah: air (70-80\%) dan zat kering
(20-30\%), jika diuraikan lagi zat kering tersebut mengandung bahan organik: $18-27 \%$ (International Training Workshop, 2010).

Pola pemupukan ikut menentukan tingkat pertumbuhan dan produksi tanaman (Georgiadis, 2007). Pupuk organik dan pupuk buatan (anorganik) dalam penggunaannya mempunyai kelebihan dan kekurangan, dapat diberikan pada tanaman secara sendiri sendiri dan kemungkinan dapat diberikan secara bersama atau kombinasi. Arnawa (2014) mendapatkan bahwa penggunaan limbah biogas (slurry) dengan dosis 10-30 ton/ha memberikan pengaruh yang sama terhadap pertumbuhan dan produksi rumput benggala (Panicum maximum cv. Trichoglume). Susanti (2016) melalui percobaan di lapangan bahwa pemberiaan pupuk bio slurry 5-15 ton/ha tidak berpengaruh terhadap pertumbuhan dan produksi Stylosanthes guianensis. Witariadi dan Kusumawati (2018) mendapatkan bahwa pemberian bioslurry dosis 30 ton/ha pada tanaman Clitoria ternatea memberikan respon pertumbuhan dan produksi tertinggi dengan kandungan protein: 22,07\%. Kombinasi pemberian antara pupuk kandang (kotoran ayam) pada level $7.500 \mathrm{~kg} / \mathrm{ha} /$ defoliasi dengan dosis urea hingga $300 \mathrm{~kg} / \mathrm{ha} /$ defoliasi, memberikan tingkat pertumbuhan terbaik pada rumput raja ( Hendarto dan Suwarno 2013).

Berdasarkan uraian di atas, pola kombinasi atau subsitusi pemupukan belum banyak informasi, maka dirasa perlu melakukan penelitian tentang efek substitusi pupuk urea sebagai sumber nitrogen dengan bio slurry (sapi dan babi) pada berbagai dosis terhadap produktivitas rumput Panicum maximum cv. Trichoglume.

\section{MATERI DAN METODE}

\section{Tempat dan Waktu Penelitian}

Penelitian dilaksanakan di rumah kaca Desa Sading, Badung selama tiga bulan, untuk melihat produktivitas rumput Panicum maximum cv. Trichoglume. Analisa proksimat untuk mengetahui kualitas rumput dilakukan di Laboratorium Nutrisi dan Makanan Ternak Fakultas Peternakan Universitas Udayana.

\section{Bibit Rumput Panicum maximum cv Tricho- glume}

Rumput yang digunakan pada penelitian ini adalah rumput Panicum maximum cv Trichoglume. Bibit berupa stek diperoleh dari stasiun penelitian Fakultas Peternakan Universitas Udayana di Desa Pengotan, Kabupaten Bangli. Penanaman bibit rumput dengan menanam stek pada tempat pembibitan, selanjutnya setelah rumput tumbuh baru dipindahkan ke pot percobaan. 


\section{Tanah dan Air}

Tanah yang digunakan untuk penelitian diambil dari lahan disekitar rumah kaca di Desa Sading, Badung. Tanah yang diambil dikering udarakan, kemudian tanah diayak dengan mengunakan ayakan kawat $(2 \mathrm{~mm} \times 2 \mathrm{~mm})$. Air yang digunakan untuk keperluan menyiram tanaman berasal dari air sumur tempat penelitian. Tanah sebelum digunakan dalam percobaan dianalisa di Laboratorium Ilmu Tanah, Fakultas Pertanian Universitas Udayana (Tabel 1)

\section{Pupuk}

Pupuk yang digunakan adalah pupuk anorganik dan pupuk organik. Pupuk anorganik (urea) sebagai sumber nitrogen $(\mathrm{N})$ dengan kandungan $\mathrm{N}$ (46\%), diperoleh dari kios pertanian. Pupuk organik (slurry) yang digunakan dalam penelitian ini diperoleh dari kelompok simantri di Giayar. Slurry terlebih dahulu dibersihkan dari sampah yang ada, selanjutnya dikeringkan, setelah kering diayak, selanjutnya slurry siap difermentasi selama 2 minggu. Pupuk fermentasi (bio slurry) sebelum diaplikasikan ke tanaman dianalisa di Laboratorium Ilmu Tanah, Fakultas Pertanian Universitas Udayana (Tabel 1.1).

\section{Rancangan Percobaan}

Penelitian menggunakan rancangan acak lengkap (RAL) terdiri dari tujuh perlakuan dan setiap perlakuan diulang lima kali, sehingga jumlah seluruh pot yang dipergunakan adalah 35 pot. Persamaan matematika dari rancangan acak lengkap (RAL) sebagai berikut:

$$
\underset{\text { Keterangan: }}{\text { Yijk }}=\mu+\tau i+\sum \mathrm{ij}
$$

i : $1,2,3,4,5,6,7$ (perlakuan)

$\mathrm{j}: 1,2,3,4,5$ (Ulangan)

Yijk : Hasil pengamatan peubah pada pemupukan ke-i dengan ulangan ke-j
$\mu$ : Rata-rata pengamatan
i : Pengaruh pemupukan ke-i
$\sum \mathrm{ij}$ : Galat percobaan dari galat ke-i pada pengamatan ke-j

Adapun perlakuan yang diberikan meliputi: perlakuan A: $200 \mathrm{~kg}$ urea/ha, perlakuan B: $150 \mathrm{~kg}$ urea/ha +10 ton bioslurry sapi/ha, perlakuan C: 100 $\mathrm{kg}$ urea/ha +20 ton bioslurry sapi/ha, perlakuan D: $50 \mathrm{~kg}$ urea/ha +30 ton bioslurry sapi/ha, perlakuan E: $150 \mathrm{~kg}$ urea/ha +10 ton bioslurry babi/ha, perlakuan F: $100 \mathrm{~kg}$ urea/ha +20 ton bio slurry babi/ha, dan perlakuan G: $50 \mathrm{~kg}$ urea/ha +30 ton bioslurry babi/ha.

\section{Variabel yang Diamati}

Variabel yang diamati pada penelitian ini meliputi:

\section{Tinggi tanaman (cm)}

Pengukuran tinggi tanaman dilakukan dengan cara mengukur tinggi tanaman dari pangkal batang tepat di atas permukaan tanah sampai dengan pangkal daun teratas yang telah berkembang sempurna.

\section{Jumlah anakan dan cabang (batang)}

Pengamatan jumlah anakan dan cabang dilakukan dengan cara menghitung tunas dan cabang yang telah berkembang sempurna.

\section{Jumlah daun (helai)}

Pengamatan jumlah daun dilakukan dengan menghitung jumlah daun yang telah berkembang sempurna.

\section{Luas daun per pot $\left(\mathrm{cm}^{2}\right)$}

Luas daun per pot didapat dengan mengambil beberapa sampel daun yang dianggap bisa mewakili setiap unit percobaan, luasnya diukur dengan alat pengukur luas daun (leaf area meter), dan hasil pengukuran dikonversikan berdasarkan data jumlah daun unit percobaan bersangkutan.

Tabel 1. Hasil Analisa Tanah, Slurry Sapi, Slurry Babi, Bio Slurry Sapi dan Bio Slurry Babi

\begin{tabular}{|c|c|c|c|c|c|}
\hline Uraian & Tanah & $\mathrm{s}$ & BS & B & $\mathrm{BB}$ \\
\hline $\mathrm{pH}(1: 2,5) \mathrm{H}_{2} \mathrm{O}$ & $6,8(N)$ & $7,10(N)$ & $6,9(N)$ & $6,7(N)$ & $6,7(\mathrm{~N})$ \\
\hline $\mathrm{DHL}(\mathrm{mmhos} / \mathrm{cm})$ & 6,64 (ST) & $3,90(\mathrm{~T})$ & $3,42(T)$ & $3,25(\mathrm{~T})$ & $3,10(\mathrm{~T})$ \\
\hline C Organik (\%) & 0,21 (SR) & 18,16 (ST) & 18,75 (ST) & 17,81 (ST) & 19,62 (ST) \\
\hline N Total (\%) & $0,19(\mathrm{R})$ & 0,83 (ST) & $0,25(\mathrm{~S})$ & $0,20(\mathrm{R})$ & $0,28(\mathrm{~S})$ \\
\hline P Tersedia (ppm) & 469,85 (ST) & 593,51 (ST) & $28,19(\mathrm{~T})$ & 886,47 (ST) & 847,08 (ST) \\
\hline K Tersedia (ppm) & $324,91(T)$ & 1154,01 (ST) & $131,51(R)$ & 1104,30 (ST) & 1266,78 (ST) \\
\hline \multicolumn{6}{|l|}{ Kadar Air : } \\
\hline KU (\%) & 5,21 & 9,70 & 13,21 & 7,53 & 11,91 \\
\hline KL (\%) & 21,40 & & & & \\
\hline \multicolumn{6}{|l|}{ Tekstur (Lempung) } \\
\hline Pasir (\%) & 47,03 & & & & \\
\hline Debu (\%) & 41,28 & & & & \\
\hline Liat (\%) & 11,68 & & & & \\
\hline
\end{tabular}

Keterangan :

Singkatan:

DHL : Daya Hantar Listrik

KU : Kering Udara

$\mathrm{KL}$ : Kapasitas Lapang

P, K : Posfor,Kalium

$\mathrm{C}, \mathrm{N}$ : Karbon, Nitrogen

$\begin{array}{ll}\text { Metode: } & \\ \text { C Organik } & : \text { Metode Walkley \& Black } \\ \text { N Total } & : \text { Metode Kjelhall } \\ \text { KU dan KL } & : \text { Metode Graviment } \\ \text { P } & : \text { Metode bray-1 } \\ \text { Tekstur } & : \text { Metode Pipet }\end{array}$

Keterangan:

R,S : Sampel :

R,S : Rendah, Sedang BB $\quad$ : Bio slurry Babi
T : Tinggi

ST : Sangat Tinggi B : Slurry Babi

$\mathrm{N}$ : Netral $\mathrm{S}:$ Slurry Sapi 
Tabel 2. Pengaruh Substitusi Pupuk Urea dengan Pupuk Bio Slurry terhadap Pertumbuhan Rumput Panicum maximum cv .Trichoglume Selama Penelitian

\begin{tabular}{|c|c|c|c|c|c|c|c|c|}
\hline \multirow{2}{*}{ Variabel } & \multicolumn{7}{|c|}{ Perlakuan $^{1)}$} & \multirow{2}{*}{$\mathrm{SEM}^{3)}$} \\
\hline & A & B & C & D & $\mathrm{E}$ & $\mathrm{F}$ & G & \\
\hline Tinggi tanaman(g) & $82,80^{\mathrm{a} 2)}$ & $85,80^{a}$ & $76,60^{a}$ & $89,20^{a}$ & $82,60^{a}$ & $85,40^{a}$ & $90,20^{a}$ & 5,68 \\
\hline Jumlah cabang(batang) & $5,80^{a}$ & $6,40^{a}$ & $7,20^{a}$ & $7,40^{\mathrm{a}}$ & $7,60^{a}$ & $7,80^{a}$ & $9,40^{a}$ & 1,07 \\
\hline Jumlah anakan (batang) & $3,00^{a}$ & $1,80^{a}$ & $2,20^{\mathrm{a}}$ & $2,40^{a}$ & $2,20^{a}$ & $2,60^{a}$ & $4,20^{a}$ & 0,58 \\
\hline Jumlah daun (helai) & $49,20^{b}$ & $60,60,20^{b}$ & $61,40^{\mathrm{b}}$ & $62,62,40^{b}$ & $62,62,80^{b}$ & $63,60^{\mathrm{b}}$ & $92,40^{\mathrm{a}}$ & 5,70 \\
\hline
\end{tabular}

Keterangan

1) A: $200 \mathrm{~kg}$ urea/ha, B:150 kg urea/ha+10t on bio slurry sapi/ha, C:100 kg urea/ha+20 ton bios/urry sapi /ha, D: $50 \mathrm{~kg}$ urea/ha+30 ton bio slurry sapi/ha, E: $150 \mathrm{~kg}$ urea/ha+10 ton bio slurry babi/ha, F:100 kg urea/ha+20 ton bio slurry/ha, G: $50 \mathrm{~kg}$ urea/ha+30ton bio slurry babi/ha

2) Nilai dengan huruf yang sama pada baris yang sama menunjukkan berbeda tidak nyata $(P>0,05)$

3) SEM: Standard Error of the Treatments Means

\section{Berat kering daun (g)}

Berat kering daun didapat dengan menimbng daun tanaman per pot plastik yang telah dikeringkan dalam oven dengan suhu $70^{\circ} \mathrm{C}$ hingga mencapai berat konstan.

\section{Berat kering batang (g)}

Berat kering batang didapat dengan menimbang batang tanaman per pot yang telah dikeringkan dalam oven dengan suhu $70^{\circ} \mathrm{C}$ hingga mencapai berat konstan.

\section{Nisbah berat kering daun/berat kering batang}

Nisbah berat kering daun dengan berat kering batang didapat dengan membagi berat kering daun dengan berat kering batang

\section{Berat kering total hijauan (g)}

Berat kering total hijauan di dapat dengan menjumlahkan berat kering batang dengan berat kering daun

\section{Analisis Statistik}

Data yang diperoleh dianalisis dengan sidik ragam. Apabila diantara nilai rata-rata perlakuan menunjukkan perbedaan yang nyata, maka analisis dilanjutkan dengan uji jarak berganda Duncan (Program SPSS).

\section{HASIL DAN PEMBAHASAN}

Hasil penelitian menunjukkan bahwa variabel tinggi tanaman, jumlah cabang dan jumlah anakan rumput Panicum maximum cv. Trichoglume yang disubstitusi pupuk urea dengan pupuk bioslury (sapi atau babi) berbeda tidak nyata (Tabel 2). Hasil ini memberikan gambaran, walaupun diberikan tambahan pupuk sesuai perlakuan ternyata kemampuan rumput memanfaatkan hara tersebut hampir sama. Unsur hara yang tersedia digunakan oleh tumbuhan pada awal pertumbuhan yaitu untuk mendukung pertumbuhan vegetatif (pertumbuhan vertikal, pembentukan anakan dan cabang). Salah satu faktor yang mempengaruhi pertumbuhan tanaman adalah kandungan hara yang terdapat di dalam tanah. Hasil analisa tanah (Tabel 1) menunjukkan kandungan hara nitrogen tanah rendah begitu juga kandungan bahan organik tanah sangat rendah. Nitrogen merupakan unsur hara utama bagi pertumbuhan tanaman sebab nitrogen sebagai penyusun dari semua protein dan asam nukleat serta merupakan penyusun protoplasma secara keselurahan (Syarief, 1986). Kekurangan unsur hara $\mathrm{N}$ menyebabkan tanaman akan menjadi kerdil, bunga terbentuk sebelum waktunya dan tidak sempurna. Kandungan bahan organik tanah berperan sebagai faktor pengendali (regulating factor) dalam proses-proses penyediaan unsur hara bagi tanaman dan mempertahankan struktur tanah melalui pembentukan agregat tanah yang stabil, penyediaan jalan bagi pergerakan air dan udara tanah, pengurangan bahaya erosi dan pencegahan pencucian hara (nutrient leaching). Keberadaan bahan organik dalam tanah seringkali dijadikan sebagai indikator umum kesuburan tanah.

Kombinasi pemakaian pupuk urea dengan bioslurry (babi atau sapi) ternyata dapat meningkatkan pertumbuhan rumput dibandingkan hanya dipupuk dengan urea saja, dimana hasil terbaik terlihat pada kombinasi pemakaian $50 \mathrm{~kg}$ urea /ha dengan 30 ton bioslurry babi/ha (G). Bioslurry dari kotoran babi lebih cepat mengalami penguraian atau terdegredasi, sehingga unsur hara lebih cepat tersedia untuk pertumbuhan tanaman. Bioslurry babi atau sapi sama-sama memberikan manfaat untuk memperbaiki struktur fisik tanah sehingga tanah menjadi lebih gembur, meningkatkan kemampuan tanah mengikat atau menahan air lebih lama yang bermanfaat saat musim kemarau, meningkatkan kesuburan tanah dan meningkatkan aktivitas cacing dan mikroorganisme tanah yang bermanfaat untuk tanah dan tanaman. Rumput yang disubstitusi pupuk urea dengan bioslurry babi atau sapi memberikan hasil lebih tinggi pada semua variabel dibandingkan hanya diberikan urea saja. Ketersedian unsur hara dari kombinasi pemakain pupuk urea dengan bioslurry babi atau sapi akan dimanfaatkan oleh rumput untuk mendukung pertumbuhan.

Terjadinya keseimbangan ketersediaan hara di tanah pada perlakuan $50 \mathrm{~kg}$ urea/ha dengan 30 ton 
Tabel 3. Pengaruh Substitusi Pupuk Urea dengan Pupuk Bio Slurry Terhadap Produksi Rumput Panicum maximum cv. Trichoglume Selama Penelitian

\begin{tabular}{|c|c|c|c|c|c|c|c|c|}
\hline \multirow{2}{*}{ Variabel } & \multicolumn{7}{|c|}{ Perlakuan $^{1)}$} & \multirow{2}{*}{$\mathrm{SEM}^{3)}$} \\
\hline & A & B & $\mathrm{C}$ & D & $\mathrm{E}$ & $\mathrm{F}$ & G & \\
\hline Berat kering daun (g) & $2,24^{b 2)}$ & $2,48^{b}$ & $2,54^{b}$ & $2,72^{b}$ & $2,82^{b}$ & $3,06^{b}$ & $5,06^{a}$ & 0,47 \\
\hline Berat kering batang (g) & $4,36^{b}$ & $4,28^{b}$ & $3,92^{b}$ & $3,88^{b}$ & $3,96^{\mathrm{b}}$ & $5,16^{\mathrm{ab}}$ & $6,54^{a}$ & 0,60 \\
\hline Berat kering total hijauan (g) & $6,6,60^{b}$ & $6,6,76^{b}$ & $6,6,46^{b}$ & $6,6,60^{b}$ & $6,6,78^{b}$ & $8,8,22^{b}$ & $1111,60^{a}$ & $1,01,00$ \\
\hline
\end{tabular}

Keterangan:

1) A: $200 \mathrm{~kg}$ urea/ha, B:150 kg urea/ha+10t on bio slurry sapi/ha, C:100 kg urea/ha+20 ton bios/urry sapi /ha, D: $50 \mathrm{~kg}$ urea/ha+30 ton bio slurry sapi/ha, E: $150 \mathrm{~kg}$ urea/ha+10 ton bio slurry babi/ha, F:100 kg urea/ha+20 ton bio slurry/ha, G: $50 \mathrm{~kg}$ urea/ha+30ton bio slurry babi/ha

2) Nilai dengan huruf yang sama pada baris yang sama menunjukkan berbeda tidak nyata $(P>0,05)$

3) SEM: Standard Error of the Treatments Means

Tabel 4. Pengaruh Substitusi Pupuk Urea dengan Pupuk Bio Slurry terhadap Karakteristik Tumbuh Rumput Panicum maximum cv. Trichoglume Selama Penelitian

\begin{tabular}{|c|c|c|c|c|c|c|c|c|}
\hline \multirow{2}{*}{ Variabel } & \multicolumn{7}{|c|}{ Perlakuan $^{1)}$} & \multirow{2}{*}{ SEM $^{3)}$} \\
\hline & A & B & C & D & E & $\mathrm{F}$ & G & \\
\hline Luas Daun per Pot $\left(\mathrm{cm}^{2}\right)$ & $4592,87^{c}$ & $5512,95^{b c}$ & $6092,71^{b c}$ & $5671,21^{b c}$ & $5301,62^{b c}$ & $7131,78^{b}$ & $9833,15^{a}$ & 745,63 \\
\hline Nisbah BK Daun/BK Batang & $0,51^{\mathrm{a} 2)}$ & $0,60^{\mathrm{a}}$ & $0,90^{\mathrm{a}}$ & $0,67^{a}$ & $0,71^{a}$ & $0,60^{a}$ & $0,68^{a}$ & 0,13 \\
\hline
\end{tabular}

Keterangan

1) A: $200 \mathrm{~kg}$ urea/ha, B:150 kg urea/ha+10t on bio slurry sapi/ha, C:100 kg urea/ha+20 ton bios/urry sapi /ha, D: $50 \mathrm{~kg}$ urea/ha+30 ton bio slurry sapi/ha, E: $150 \mathrm{~kg}$ urea/ha+10 ton bio slurry babi/ha, F:100 kg urea/ha+20 ton bio slurry/ha, G: $50 \mathrm{~kg}$ urea/ha+30ton bio slurry babi/ha

2) Nilai dengan huruf yang sama pada baris yang sama menunjukkan berbeda tidak nyata $(P>0,05)$

3) SEM: Standard Error of the Treatments Means

bioslurry babi/ha (G) secara nyata meningkatkan pertumbuhan jumlah daun, berat kering daun, berat kering batang, berat kering total hijaun (Tabel 3) dan luas daun per pot (Tabel 4) rumput Panicum maximum cv. Trichoglume. Pupuk urea sebagai sumber nitrogen merupakan unsur hara utama yang dipergunakan oleh tumbuhan untuk pembentukan dan pertumbuhan bagian-bagian vegetatif tanaman seperti: daun, batang, dan akar serta meningkatkan kandungan klorofil (Sutedjo, 2002). Pertumbuhan daun yang banyak akan membantu mempercepat proses fotosintesis dan terjadi peningkatan klorofil daun sebagai bahan penyusun protein dan lemak yang hasilnya ditranslokasikan ke bagian lain dari tanaman dan digunakan untuk pertumbuhan vegetatif dan generatif (Djoehana, 1986). Semakin meningkat dosis pupuk bioslurry diberikan pada tanaman, maka makin tinggi tingkat pertumbuhan dan produksi tanaman begitu juga terhadap penampilan karakteristik tumbuh yaitu memiliki luas daun yang lebih lebar. Luas daun yang lebar memungkinkan tanaman untuk meningkatkan proses fotosintesis. Kapasitas fotosintesis yang berlangsung lebih tinggi, sehingga hasil fotosintesis yang dihasilkan berupa karbohidrat dan protein memberikan hasil maksimal. Karbohidrat dan protein merupakan komponen penyusun berat kering tanaman, dimana semakin banyak kandungan karbohidrat dan protein dalam tanaman, maka berat kering tanaman semakin tinggi (Budiana 1993). Tingginya berat kering tanaman akan berpengaruh terhadap nisbah berat kering daun dengan batang (Tabel 4). Nilai nisbah daun dengan batang semakin tinggi menunjukkan rumput tersebut memiliki kualitas lebih baik karena kandungan karbohidrat dan protein akan lebih banyak seiring dengan meningkatnya pertumbuhan daun.

Pemberian pupuk urea ke dalam tanah ternyata mempengaruhi sifat kimia dan biologi tanah. Fungsi kimia dan hayati yang penting diantaranya adalah selaku penukar ion dan penyangga kimia, sebagai gudang hara $\mathrm{N}, \mathrm{P}$, dan $\mathrm{S}$, pelarutan fosfat dengan jalan kompleksasi ion $\mathrm{Fe}$ dan $\mathrm{Al}$ dalam tanah dan sebagai sumber energi mikroorganisme tanah (Notohadiprawiro, 1998). Sedangkan penambahan bioslurry babi atau sapi ke dalam tanah ternyata berdampak pada peningkatan kadar C-organik tanah (Tabel 1). Perbedaan kandungan C-organik tanah akibat adanya perbedaan takaran bahan organik yang diberikan (Umar 2002). Kandungan C-organik tanah menyebabkan kondisi tanah memiliki kadar uap air tanah menjadi tinggi dimana tanah menjadi lembab sehingga populasi mikroorganisme di dalam tanah berkembang dengan baik dan mampu menguraikan bahan organik lebih cepat, serta unsur hara yang dibutuhkan oleh tanaman tersedia lebih awal. Kelembaban tanah memegang peranan yang sangat penting dalam proses metabolisme mikroba dan secara tidak langsung berpengaruh terhadap suplai oksigen.

\section{SIMPULAN}

Dari hasil penelitian dapat disimpulkan bahwa efektivitas substitusi pupuk urea dengan bioslurry babi dapat meningkatkan pertumbuhan dan produksi rumput Panicum maximum cv. Trichoglume dan hasil terbaik apabila rumput tersebut disubstitusi dengan $50 \mathrm{~kg}$ urea/ha dengan 30 ton bioslurry babi/ha. 


\section{UCAPAN TERIMAKASIH}

Pada kesempatan ini penulis mengucapkan banyak terimakasih kepada Rektor dan Ketua LPPM atas dana yang diberikan melalui DIPA PNBP Universitas Udayana, sehingga penelitian dan penulisan artikel ilmiah dapat terlaksana.

\section{DAFTAR PUSTAKA}

Arnawa, I W. 2014. Pertumbuhan dan Produksi Rumput Benggala (Panicum Maximum cv.Trchoglume) yang diberi Pupuk Organik dengan Dosis Berbeda. Skripsi. Fakultas Peternkan Universitas Udayana. Denpasar.

Aganga and Tshwenyane. 2004. Potentials of guinea grass (Panicum maximum) as forage crop in livestock production. Pakistan Journal of Nutrition 3:1-4.

Budiana. 1993. Produksi Tanaman Hijauan Pakan Ternak Tropis, Fakultas Peternakan Gajah Mada, Yogyakarta.

Deinum, B. 1966. Climate, Nitrogen and Grass. Depart Field. Crops. Husb. Agric. University Weghingen the Netherland.

Djoehana, S. 1986. Pupuk dan Pemupukan, Cetakan Pertama. CV. Simplex.

Georgiadis, N.J., 2007. Savana Herbivore Dynamics In A Livestock-Dominated Landscape. II: Ecological, Conservation, And Management Implication Of Predator Restoration. Journal of Biological Conservation, 137 (3): 2007-2012.

Hendarti. E dan Suwarno. 2013. Pengaruh Kombinasi Pupuk Kandang dan Urea pada Tampilan Aspek Pertumbuhan Tanaman Rumput Raja pada Pemanenan Defoliasi ke Empat .Bionatura, Jurnal Ilmu-ilmu Hayati Vol: 15 No.2;8388. Fakultas Peternakan Universitas Jendral Soedirman, Purwekerto,Jawa Tengah.
Internasional Training Workshop. 2010.Training Material of Biogas Technology.Yunan Normal University Yunan,China. P 102.

Notohadiprawiro.1998. Tanah dan Lingkungan. Penerbit Jakarta.

Rustandi. 1982. Pengaruh Tingkat Pemupukan Kalium dan Tinggi Pemotongan terhadap Produksi dan Mutu Hijauan Rumput Gajah. Skripsi, LPP. Unsrat Menado.

Susanti N. R., A.A.A.S Trisnadewi, dan N M. Witariadi. 2016. Pertumbuhan dan Produksi Hijauan Stylosanthes guianensis pada Berbagai Level Aplikasi Pupuk Bio-slurry. E-jurnal Peternakan Tropika. https://ojs.unud.ac.id/index.php/ tropika/article/view/22957Sutedjo, M. M. 2002. Pupuk Dan Cara Penggunaan. Jakarta: Rineka Cipta.

Syarief, W. N. 1986. Dasar-dasar Pemupukan. Penerbit CV. Bina Aksara. Jakarta.

Suarna, I W.1997. Peranan Pupuk Organik Kascing dalam Sistem Poduksi Hijauan Terpadu di Lahan Kering. Program Pasca Sarjana Universitas Padjajaran Bandung.

Tata, T. 1995. Pengaruh Jenis dan Dosis Kotoran Ternak Terhadap Produktifitas Arachis pintoi. Skripsi. Fakultas Peternakan Universitas Udayana. Denpasar.

Umar. 2002. Pengaruh Takaran Pupuk Tembaga dan Bahan Organik Terhadap Pertumbuhan dan Hasil Kedelai di Tropudult. Tesis. PS. Agronomi Ilmu-ilmu Pertanian. Universitas Gadjah Mada. Yogyakarta.

Witariadi, N.M., dan Candraasih.K. 2016. Produktivitas dan Komposisi Kimia Tanaman Leguminosa (Centrocema pubescen dan Clitoria ternatea) yang Dipupuk dengan Pupuk Bio Slurry. Majalah Ilmiah Peternakan Vol.20 No 3 Tahun 2017.

Witariadi, N. M. dan N. N. Candraasih K. 2018. Produktivitas rumput Panicum maximum yang dipupuk dengan jenis dan dosis bio slurry berbeda. Jurnal Pastura,vol 7, no 2 